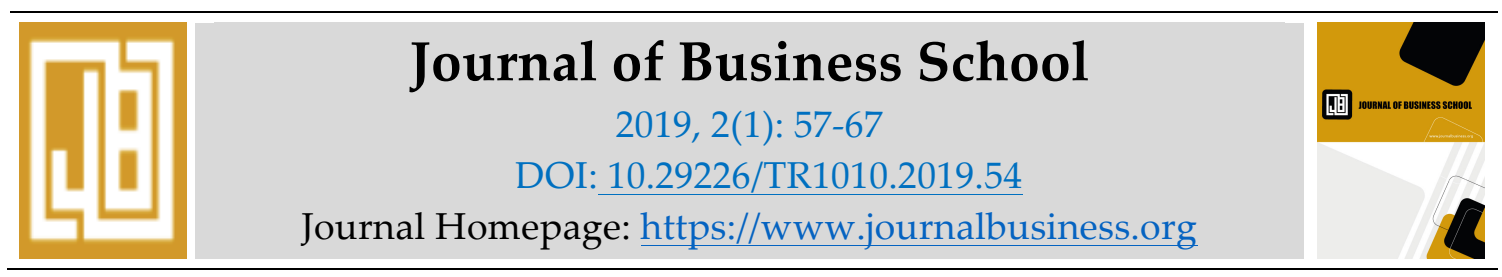

\title{
Economic Aspects of Literacy on Humans in District Nowshera
}

\author{
Mr. Asad Khan MPhil Scholar \\ Department of education, University of Haripur, Khyber Pakhtunkhwah, Pakistan \\ asadadamzai@yahoo.com
}

Dr. Muhammad Saeed Khan

Assistant Professor Department of Education, University of Haripur

Miss Mahnaz Iqbal Yousafzai

PhD Scholar, Department of Education, Northern University Nowshera, Khyber

Pakhtunkhwah, Pakistan mahnazyousafzai@yahoo.com

\section{Kifayat Khan}

Lecturer Department of Education, University of Haripur,Khyber Pakhtunkhwah, Pakistan Kifayatkhan@uoh.edu.pk

\begin{abstract}
Development of a nation is measured by its literacy rate. In Pakistan different literacy programs are underway but still we are far away from the desired destination. The study entitled "Economic aspects of literacy on the lives of humans in District Nowshera" was to find out the blessings and areas of development by literacy and the hurdles that are being created by illiteracy. It was a survey type study and the population was divided into four zones. For convenience a sample size of 256 households were selected for survey. The total population from 256 households was 1551 persons in which 1115 persons were aged 10-59 years. The desired literates were 288 out of which 215 participated in the survey. The collected data was administered using statistical procedures like sum, mean and t-test. The results of the study were identified considerable development in the standard of the literate lives and found out significance disparity between male and female and rural and urban. It was suggested that government and NGOs should give priority to literacy by keeping strict check and balance policy and give incentives to literates.
\end{abstract}

Keywords: Economics, Development, Literacy 


\section{Introduction}

Literacy can be defined in several thinkable denotations; it is the capability of persons how to manage with communications living in their customs and traditions (Strassman, 1983). Literacy is just like collection of skills together with the capacity to accomplish undeveloped understanding and mathematical responsibilities essential for the fitness maintenance situations. Reading, writing and numeracy are expected to be the base line for literacy. Reading 30 words per minute, writing 7 words per minute and writing and reading numerals from 1 to 100 are the basic abilities of a literate person (Mitra, 2007).

In the worldwide perception, Literacy can be defined in Bangladesh as the capability to read and write in any local or foreign language while grade $9^{\text {th }}$ passed is counted as literate in Canada. In India, an individual reading approximately 40 words in a minute, having writing speed of 10 words in a minute and yielding a dictation of 7 words in a minute in any language is measured literate. The one aged 10 or more and has been admitted in school is considered as literate in Malaysia. An individual who can only read and write is counted as literate in Tajikistan. UNESCO (2008) defines literate internationally as "a person reading and writing with comprehension a simple statement in any linguistic and can perform simple daily life arithmetic."

In Pakistani National context, literacy definitions have been changed from time to time. In the census of 1951 literacy was defined as "an individual who can read from a printing material in any language". After 10 years in 1961 the definition was enhanced as literate is a person who can read with comprehension a simple letter in any verbal communication. In the 1972 census writing was also included with reading. According to 1972 census a literate person is the one who can read and write with understanding in any language. In the era of Marshal Law in 1981 a literate individual was the one who has the ability in reading newspaper and to writing an artless letter. In 1998 the previous definition of literacy was modified as a literate person is expected to recite newspaper and carve a letter in any dialectal (Government of Pakistan, 2006).

Beyond reading and writing, literacy is the capacity to behave like a well-educated individual. Among reading, writing and numeracy, writing is considered the most crucial for children. All these require a guided instructions and practices (Wallace, 2004). The role of literacy in developing countries is very important (Lara, 2007). Literacy offers all types of education like political, leadership skills, vocational and social awareness. Literacy is considered to be the backbone of the progress. Literate manpower proves vital for the progress of the country. Literate people have social awareness and know the worth of the resources. They can easily utilize and convert limited resources in a much better way. They can adjust themselves in any circumstances. Literate people are considered to be the most democratic. They can solve their problems without interfering others and make a prosperous society. The previous aspect of literacy has been changed. In the present circumstances literacy is considered to be the best tool of life (Hall, 2003).

\section{Review of Related Literature}

Literacy is important in the context of developing social interaction among the public. Literate people cooperate and communicate with each other in a better way. History shows that the countries with strong political will for literacy have achieved their goals efficiently. These countries have strongly opposed the illiteracy and tried all their best to use the available resources for the eradication of illiteracy. Primary education became compulsory. In the result, developed society has been formed (Rashid, 2009). Children may have impact on economic development after ten or more years. Adults have direct impact on the economic development. 
Their attitude must be positively changed. So it is necessary to educate the adults first through literacy programs (Benson, 2009).

In literacy programs, learners do not attend the school regularly. It is a part time education. The curriculum is embedded and skills generating. Literacy is a short and sharp program in which the learners learn all the basic abilities in a short interval of time. Literacy brings changes in the information, knowledge and understanding of the learners and skills of life are learned. Literacy is connected with the socio economic conditions of the people. It has often showed a positive relationship with budget of the families (Justice et al., 2003).

Less developed countries have seriously felt the importance of literacy and folding their objectives in a productive way. They are bringing their mass population towards the functional literacy. Most of the adults have not passed through the formal mode of education and reluctant to adjust themselves in the formal system of education. Workers and farmers are the main target of literacy as they are in the field, so they may be given priority in the literacy programs. Pakistan saw many fluctuations in the year 2011. Due to high growth rate and low level of investment Pakistan remained behind the Millennium Development Goals (PAKISTAN One UN Program Report 2011).

Pakistan is a country which has seen many ups and downs in the field of education. Several experiences have been done to cope with the illiteracy but no program has been fully successful. In the last two decades Pakistan has steadily showed increase in the economic development. In the field of education the achievement rate is significantly low.

In Pakistan, the organized adult literacy had been initiated for the first time in 1985 under the name of "NaiRoshni." This project drew the people towards the literacy education. But unfortunately the project was soon abounded due to several constraints. A World Bank report 2010 shows that Pakistan is extremely behind the target. In Dakkkar conference declaration Pakistan expected $100 \%$ literacy by 2015 . Pakistan hardly reached the $52 \%$ mark by 2010 . The said report has found several causes of not achieving the target such as high dropout, urban/rural location, school mapping, shortage of well trained and dedicated teachers and lack of teaching materials. Political leaders and bureaucracy did not take any interest in uplifting of literacy programmes on urgency level. Budget allocations remained inadequate. According to the partially conducted census 2008 the literacy rate of Pakistan is very low i.e. 52\% with wide range variation in urban/rural and male/female basis. Literacy rate for urban population was $63 \%$ as compared to rural literacy rate of $34 \%$. There was a huge gender. Male literacy rate in urban areas was $70 \%$ against female literacy rate of $55 \%$. Similarly in rural literacy rate of males was $46 \%$ against the female literacy rate of $20 \%$. Funds were taken from the donor agencies to enhance literacy. All these efforts failed due to its sustainability (Qureshi, 2002).

Literateness proportion of Pakistan as $52.5 \%$ which is composed 63 percent of males and 38 percent of females. This indicates a wider gender gap. As far as female literateness proportion is concerned, two out of every three females are illiterate. A huge hole is present in the rural urban location. Rural literacy 39 percent is lower than urban literacy of 70 percent. In Pakistan several schools are used for different functions and self uses of the people rather than literacy. People used these schools for their animals (Saleem, 2002).

Feudal system of Pakistan is the main barrier in the uplifting of literacy. The southern Punjab, Sindh and Balochistan are main privileged areas. The current literacy position of Pakistan is not satisfactory. Several steps will be taken to enhance the status of literacy of the country. Different programs will be introduced to raise the literacy rate to $86 \%$ by 2015 (Rasheed, 2004). 


\section{Objectives of the Study}

a) Identification of literates using a household survey sheet in the population of district Nowshera.

b) To find out the economic aspects of literacy of the population.

c) Application of literacy benefits to the families of participants in district Nowshera.

\section{Research Methodology}

This was descriptive type survey research, which was engrossed on the economics aspects of literacy on humans in the selected urban and rural areas of District Nowshera. In such type of survey generally two tactics i.e. de-jure and de-fecto are used to collect data from the population. De-jure technique counts the people in their usual place of living while de-fecto technique is used to count the people in any place of their findings during the data collection period. In the current study de-jure technique has been used to collect the data from population. The collected data was tabulated on the basis of de-jure techniques. To find out the economic aspects of literates of age range of 10-59 tests was organized. De-jure and de-fecto techniques and test are mostly in social sciences.

\section{Population of the Study}

Population of the study involves of the males and females in the age group 10-59. The respondents belong to urban and rural areas of District Nowshera who have have passed $5^{\text {th }}$ grade examination and left over before completing $8^{\text {th }}$ grade level.

\section{Sample of the Study}

Large size of sample is usually assumed for accurate survey still the researcher preferred small size of sample since it was easy to achieve, visible and small cost convoluted. To collect the data the sample was stratified in 4 zones. Each zone was divided in two parts i.e. urban and rural part. 4 villages and 4 towns from each Zone of District Nowshera were unsystematically selected. Equal numbers of houses were selected from urban and rural areas. To get estimate of literates 8 houses from each village or town were randomly selected. A total of 16 villages and 16 towns were selected from the district Nowshera. Hence the number of total houses was 256. The study was instigated using the method of stratified cluster sampling. Every Zone was measured one stratum and inside each Zone the study followed the sampling method used 4 strata, each village/town was considered as cluster, so in each stratum 8 clusters were measured. Henceforth, the study comprised of a total 4 strata (4 Zones), 32 clusters from 4 Zones. Picture of sample is as below: 


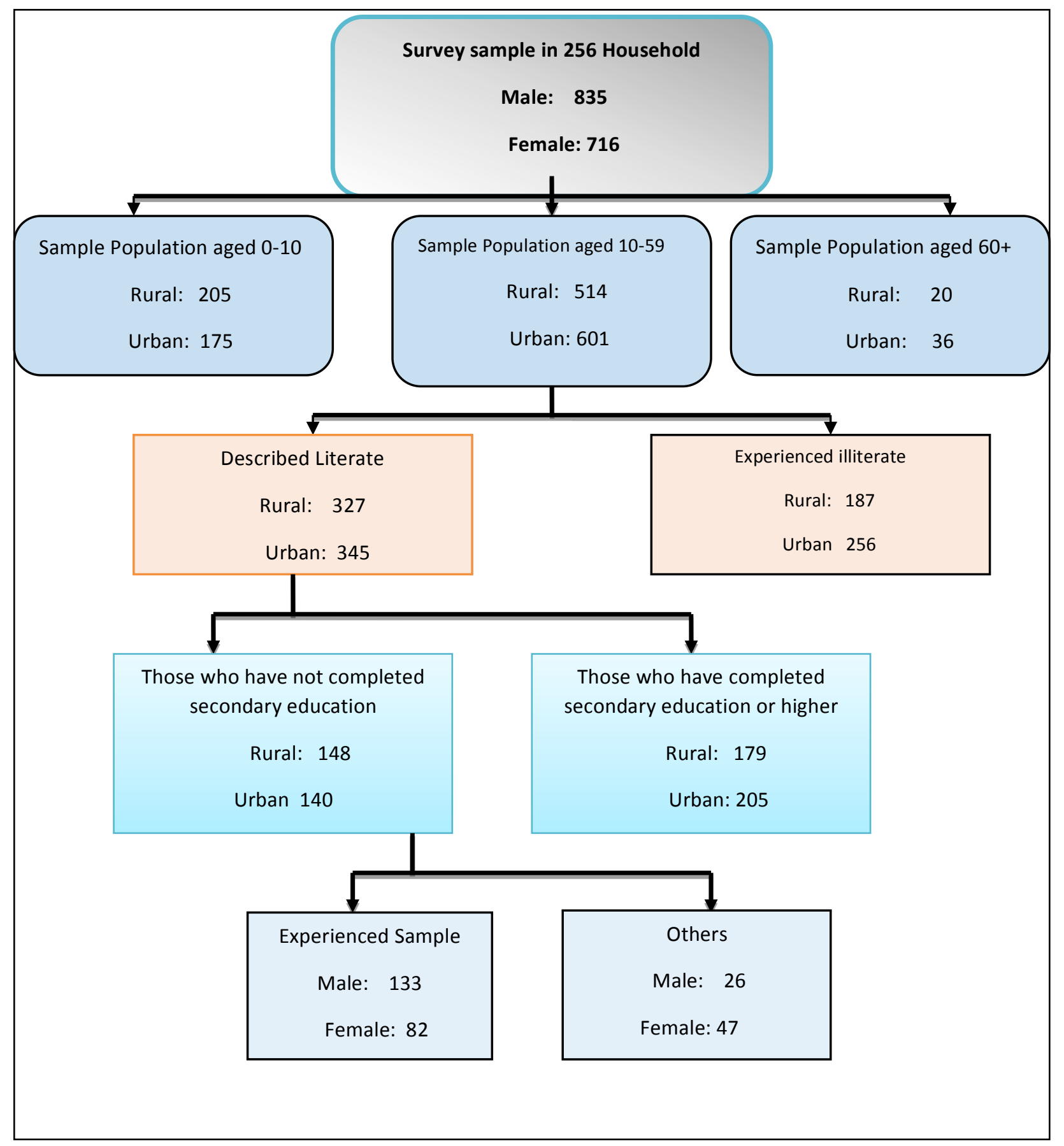

\section{Instrument of the Study}

To check the literacy rate of the respondents a questionnaire was constructed in two parts. First part was about the basic information and characteristics of the respondents while second part was about the role of literacy. Expert opinions were obtained to make the instrument valid. It was further refined through pilot testing. The reliability coefficient of the first part was 0.94 , while that of the test part was 0.85 .

\section{Data Collection and Analysis}

Data assemblage is a complex process. The researcher made plans to reach the respondents. The researcher visited and met the native leaders, prominent people, prayer's leaders and social workers to aware the respondents in the data gathering process. Introductory sessions were 
conducted to aware the respondents about the importance of the study and their role in the process of response. These sessions were very fruitful in establishing a good connection among the respondents and researcher. Convenient timing schedule for survey was drawn for the data gathering. As female respondents were also included in the study, so female health workers were haired for this purpose. In the first phase all the targeted respondents of age group 10-59 were recognized. After recognizing the targeted population, the respondents who have completed primary education but left before completing the elementary level were detached. In the second phase a questionnaire was distributed and filled with the help of Lady Health Workers (LHWs) who were already trained for this purpose. The data collected via questionnaire was encoded and analyzed through simple means and frequencies through SPSS package.

\section{FINDINGS AND DISCUSSIONS}

\section{Findings}

Table 1: Gender

\begin{tabular}{|l|l|r|r|r|r|}
\hline \multicolumn{2}{|c|}{} & Frequency & Percent & Valid Percent & Cumulative Percent \\
\hline \multirow{3}{*}{ Valid } & Male & 133 & 61.9 & 61.9 & 61.9 \\
\cline { 2 - 6 } & Female & 82 & 38.1 & 38.1 & 100.0 \\
\cline { 2 - 6 } & Total & 215 & 100.0 & 100.0 & \\
\hline
\end{tabular}

Table 1 shows that 133 males and 82 females participated in the survey.

Table 2: Zone

\begin{tabular}{|l|l|r|r|r|r|}
\hline \multicolumn{2}{|l|}{} & \multicolumn{1}{|c|}{ Frequency } & \multicolumn{1}{|c|}{ Percent } & Valid Percent & Cumulative Percent \\
\hline \multirow{5}{*}{ Valid } & Pabbi & 48 & 22.3 & 22.3 & 22.3 \\
\cline { 2 - 6 } & Nowshera & 67 & 31.2 & 31.2 & 53.5 \\
\cline { 2 - 6 } & Akora Khattak & 53 & 24.7 & 24.7 & 78.1 \\
\cline { 2 - 6 } & Nizampur & 47 & 21.9 & 21.9 & 100.0 \\
\cline { 2 - 6 } & Total & 215 & 100.0 & 100.0 & \\
\hline
\end{tabular}

Table 2 shows zone-wise participant. Most participants belong to Nowshera while least participants belong to Nizampur.

Table 3: Location

\begin{tabular}{|l|l|r|r|r|r|}
\hline \multicolumn{2}{|c|}{} & \multicolumn{1}{|c|}{ Frequency } & \multicolumn{1}{|c|}{ Percent } & Valid Percent & Cumulative Percent \\
\hline \multirow{3}{*}{ Valid } & Urban & 112 & 52.1 & 52.1 & 52.1 \\
\cline { 2 - 6 } & Rural & 103 & 47.9 & 47.9 & 100.0 \\
\cline { 2 - 6 } & Total & 215 & 100.0 & 100.0 & \\
\hline
\end{tabular}

Table 3 shows urban/rural location of the participants. Urban participants are more than rural participants. 
Table 4: Literacy brought change in your life

\begin{tabular}{|l|l|r|r|r|r|}
\hline \multicolumn{2}{|c|}{} & Frequency & \multicolumn{1}{|c|}{ Percent } & Valid Percent & Cumulative Percent \\
\hline \multirow{7}{*}{ Valid } & Strongly Agreed & 173 & 80.5 & 80.5 & 80.5 \\
\cline { 2 - 6 } & Agreed & 35 & 16.3 & 16.3 & 96.7 \\
\cline { 2 - 6 } & Uncertain & 4 & 1.9 & 1.9 & 98.6 \\
\cline { 2 - 6 } & Disagreed & 3 & 1.4 & 1.4 & 100.0 \\
\cline { 2 - 6 } & Total & 215 & 100.0 & 100.0 & \\
\hline
\end{tabular}

Table 4 shows that most of the participants (80.5\%) were strongly agreed that literacy changed their life.

Table 5 Literacy changed your attitude

\begin{tabular}{|l|l|r|r|r|r|}
\hline \multicolumn{2}{|c|}{} & Frequency & Percent & Valid Percent & Cumulative Percent \\
\hline \multirow{6}{*}{ Valid } & 189 & 87.9 & 87.9 & 87.9 \\
\cline { 2 - 6 } & Strongly Agreed & 20 & 9.3 & 9.3 & 97.2 \\
\cline { 2 - 6 } & Agreed & 4 & 1.9 & 1.9 & 99.1 \\
\cline { 2 - 6 } & Uncertain & 2 & .9 & .9 & 100.0 \\
\cline { 2 - 6 } & Disagreed & 215 & 100.0 & 100.0 & \\
\cline { 2 - 6 } & Total & &
\end{tabular}

Table 5 shows that most of the participants $(87.9 \%)$ were agreed that literacy changed their attitude.

Table 6: Literacy improved your temperament

\begin{tabular}{|l|l|r|r|r|r|}
\hline \multicolumn{2}{|c|}{} & Frequency & Percent & Valid Percent & Cumulative Percent \\
\hline \multirow{5}{*}{ Valid } & 188 & 87.4 & 87.4 & 87.4 \\
\cline { 2 - 6 } & Strongly Agreed & 21 & 9.8 & 9.8 & 97.2 \\
\cline { 2 - 6 } & Agreed & 4 & 1.9 & 1.9 & 99.1 \\
\cline { 2 - 6 } & Uncertain & 2 & .9 & .9 & 100.0 \\
\cline { 2 - 6 } & Disagreed & 215 & 100.0 & 100.0 & \\
\cline { 2 - 6 } & Total & & &
\end{tabular}

Table 6 shows that most of the participants $(87.4 \%)$ were stronglt agreed that literacy improved their temperament. 
Table 7: Literacy helped you in employment opportunities

\begin{tabular}{|l|l|r|r|r|r|}
\hline \multicolumn{2}{|c|}{} & \multicolumn{1}{|c|}{ Frequency } & Percent & Valid Percent & Cumulative Percent \\
\hline \multirow{6}{*}{ Valid } & Strongly Agreed & 149 & 69.3 & 69.3 & 69.3 \\
\cline { 2 - 6 } & Agreed & 35 & 16.3 & 16.3 & 85.6 \\
\cline { 2 - 6 } & Uncertain & 14 & 6.5 & 6.5 & 92.1 \\
\cline { 2 - 6 } & Disagreed & 17 & 7.9 & 7.9 & 100.0 \\
\cline { 2 - 6 } & Total & 215 & 100.0 & 100.0 & \\
\hline
\end{tabular}

Table 7 shows that most of the participants (69.3\%) were strongly agreed that literacy helped them in finding jobs.

Table 8: Literacy programs improved your skills

\begin{tabular}{|l|l|r|r|r|r|}
\hline \multicolumn{2}{|c|}{} & \multicolumn{1}{|c|}{ Frequency } & Percent & Valid Percent & Cumulative Percent \\
\hline \multirow{5}{*}{ Valid } & Strongly Agreed & 154 & 71.6 & 71.6 & 71.6 \\
\cline { 2 - 6 } & Agreed & 37 & 17.2 & 17.2 & 88.8 \\
\cline { 2 - 6 } & Uncertain & 21 & 9.8 & 9.8 & 98.6 \\
\cline { 2 - 6 } & Disagreed & 3 & 1.4 & 1.4 & 100.0 \\
\cline { 2 - 6 } & Total & 215 & 100.0 & 100.0 & \\
\hline
\end{tabular}

Table shows that most of the participants $(71.6 \%)$ were strongly agreed that literacy improved the internal skills of the participants.

Table 9: You are getting more earning after getting literate

\begin{tabular}{|l|l|r|r|r|r|}
\hline \multicolumn{2}{|c|}{} & \multicolumn{1}{|c|}{ Frequency } & \multicolumn{1}{|c|}{ Percent } & Valid Percent & Cumulative Percent \\
\hline \multirow{6}{*}{ Valid } & 181 & 84.2 & 84.2 & 84.2 \\
\cline { 2 - 6 } & Strongly Agreed & 26 & 12.1 & 12.1 & 96.3 \\
\cline { 2 - 6 } & Agreed & 5 & 2.3 & 2.3 & 98.6 \\
\cline { 2 - 6 } & Uncertain & 3 & 1.4 & 1.4 & 100.0 \\
\cline { 2 - 6 } & Disagreed & 215 & 100.0 & 100.0 & \\
\cline { 2 - 6 } & Total & &
\end{tabular}

Table 9 shows that most of the participants (84.2) were strongly agreed that literacy had increased their earnings.

Table 10: Literacy enabled you socially empowered

\begin{tabular}{|l|l|r|r|r|r|}
\hline \multicolumn{2}{|c|}{} & Frequency & Percent & Valid Percent & Cumulative Percent \\
\hline \multirow{5}{*}{ Valid } & Strongly Agreed & 155 & 72.1 & 72.1 & 72.1 \\
\cline { 2 - 6 } & Agreed & 56 & 26.0 & 26.0 & 98.1 \\
\cline { 2 - 6 } & Uncertain & 2 & .9 & .9 & 99.1 \\
\cline { 2 - 6 } & Disagreed & 2 & .9 & .9 & 100.0 \\
\cline { 2 - 6 } & Total & 215 & 100.0 & 100.0 & \\
\hline
\end{tabular}


Table 10 shows that most of the participants (72.1\%) were strongly agreed that literacy had made them socially empowered.

Table 11: Literacy increased your decision power

\begin{tabular}{|l|l|r|r|r|r|}
\hline \multicolumn{2}{|c|}{} & Frequency & Percent & Valid Percent & Cumulative Percent \\
\hline \multirow{7}{*}{ Valid } & Strongly Agreed & 190 & 88.4 & 88.4 & 88.4 \\
\cline { 2 - 6 } & Agreed & 17 & 7.9 & 7.9 & 96.3 \\
\cline { 2 - 6 } & Uncertain & 7 & 3.3 & 3.3 & 99.5 \\
\cline { 2 - 6 } & Disagreed & 1 & .5 & .5 & 100.0 \\
\cline { 2 - 6 } & Total & 215 & 100.0 & 100.0 & \\
\hline
\end{tabular}

Table 11 shows that most of the participants (88.4\%) were strongly agreed that their decision power was enhanced by literacy.

Table 12: Literacy increased your purchasing power

\begin{tabular}{|l|l|r|r|r|r|}
\hline \multicolumn{2}{|c|}{} & Frequency & Percent & Valid Percent & Cumulative Percent \\
\hline \multirow{7}{*}{ Valid } & 167 & 77.7 & 77.7 & 77.7 \\
\cline { 2 - 6 } & Strongly Agreed & 34 & 15.8 & 15.8 & 93.5 \\
\cline { 2 - 6 } & Agreed & 13 & 6.0 & 6.0 & 99.5 \\
\cline { 2 - 6 } & Uncertain & 1 & .5 & .5 & 100.0 \\
\cline { 2 - 6 } & Disagreed & 215 & 100.0 & 100.0 & \\
\cline { 2 - 6 } & Total & & &
\end{tabular}

Table 12 shows that most of the participants $(77.7 \%)$ were strongly agreed that their purchasing power was increased by literacy.

Table 13: Literacy. Increased your saving power

\begin{tabular}{|l|l|r|r|r|r|}
\hline \multicolumn{2}{|c|}{} & Frequency & Percent & Valid Percent & Cumulative Percent \\
\hline \multirow{3}{*}{ Valid } & 181 & 84.2 & 84.2 & 84.2 \\
\cline { 2 - 6 } & Strongly Agreed & 24 & 11.2 & 11.2 & 95.3 \\
\cline { 2 - 6 } & Agreed & 7 & 3.3 & 3.3 & 98.6 \\
\cline { 2 - 6 } & Uncertain & 3 & 1.4 & 1.4 & 100.0 \\
\cline { 2 - 6 } & Disagreed & 215 & 100.0 & 100.0 & \\
\cline { 2 - 6 } & Total & & &
\end{tabular}

Table 13 shows that most of the participants $(84.2 \%)$ were strongly agreed that their saving power was increased by literacy. 
Table 14: Your economic position upgraded in the society with literacy

\begin{tabular}{|l|l|r|r|r|r|}
\hline \multicolumn{2}{|c|}{} & Frequency & Percent & Valid Percent & Cumulative Percent \\
\hline \multirow{7}{*}{ Valid } & 158 & 73.5 & 73.5 & 73.5 \\
\cline { 2 - 6 } & Strongly Agreed & 51 & 23.7 & 23.7 & 97.2 \\
\cline { 2 - 6 } & Agreed & 4 & 1.9 & 1.9 & 99.1 \\
\cline { 2 - 6 } & Uncertain & 1 & .5 & .5 & 99.5 \\
\cline { 2 - 6 } & Disagreed & 1 & .5 & .5 & 100.0 \\
\cline { 2 - 6 } & 11.00 & 215 & 100.0 & 100.0 & \\
\cline { 2 - 6 } & Total & & & \\
\hline
\end{tabular}

Table 14 shows that most of the participants (73.5\%) were strongly agreed that literacy had upgraded their economic position in the society.

Table 15: Your family educational status improved with your literacy

\begin{tabular}{|l|l|r|r|r|r|}
\hline \multicolumn{2}{|c|}{} & Frequency & \multicolumn{1}{|c|}{ Percent } & Valid Percent & Cumulative Percent \\
\hline \multirow{3}{*}{ Valid } & 140 & 65.1 & 65.1 & 65.1 \\
\cline { 2 - 6 } & Strongly Agreed & 68 & 31.6 & 31.6 & 96.7 \\
\cline { 2 - 6 } & Agreed & 4 & 1.9 & 1.9 & 98.6 \\
\cline { 2 - 6 } & Uncertain & 3 & 1.4 & 1.4 & 100.0 \\
\cline { 2 - 6 } & Disagreed & 215 & 100.0 & 100.0 & \\
\cline { 2 - 6 } & Total & &
\end{tabular}

Table 15 shows that most of the participants $(65.1 \%)$ were strongly agreed that literacy had improved the educational status of their children.

Table 16: Your standard of life improved with literacy

\begin{tabular}{|l|l|r|r|r|r|}
\hline \multicolumn{2}{|c|}{} & Frequency & Percent & Valid Percent & Cumulative Percent \\
\hline \multirow{3}{*}{ Valid } & 175 & 81.4 & 81.4 & 81.4 \\
\cline { 2 - 6 } & Strongly Agreed & 32 & 14.9 & 14.9 & 96.3 \\
\cline { 2 - 6 } & Agreed & 6 & 2.8 & 2.8 & 99.1 \\
\cline { 2 - 6 } & Uncertain & 2 & .9 & .9 & 100.0 \\
\cline { 2 - 6 } & Disagreed & 215 & 100.0 & 100.0 & \\
\cline { 2 - 6 } & Total & & & \\
\hline
\end{tabular}

Table 16 shows that most of the participants (81.4\%) were strongly agreed that literacy had improved their standard of life.

\section{Discussions}

It has been observed that literacy had brought a tremendous change in the lives of participants. Literate people are playing a remarkable role in the society. A simple literate person considers education a necessary tool against the poverty. They are spending on family education although they got literate in the last stage of their lives. Literate people ave increased their purchasing and saving powers. Literacy helped them in finding their jobs and they are earning more and more. 


\section{Recommendations}

It is necessary that there must be a strong communication between the literacy establishments and noteworthy inhabits of the community. Improved incentives for literacy instructors and learners may be reserved in provisions. Further, rooted and profession oriented curriculum for literacy may be developed. And the process of valuation and observation must be reinforced. Furthermore, technical and vocational programs may be embedded in the literacy programs. Along this, female enrolment ratio may be enhanced through incentive programs. Last but not the least; a well-adjusted methodology is to be developed in order to improve the reading, writing, numeracy and visual skills of learners.

\section{References}

Asif. M.F. (2013). Identification of Gaps between Reported and Tested Literacy rates in selected areas of District Faisalabad, Pakistan. International Journal of Academic Research and Reflection Vol. 1 No. 2 July 2013: ISSN 2309-0405 (Online) ISSN 2308-8249 (Print)

Benson, H. S. (2009). Campaigning for Literacy, The Challenges and polices of media literacy programs in Egyptian schools: Turkey, UNESCO.

Government of Pakistan (2006b). Green Papers: National Education Policy Review Process. Islamabad: Ministry of Education,

Hall, N., Larson, J., \& Marsh, J. (Eds.). (2003). Handbook of early childhood literacy. London: Sage.

Justice, L.M., Chow, S., Capellini, C., Flannigan, K., \& Colton, S. (2003). Emergent literacy intervention for vulnerable preschoolers: Relative effects of two approaches. American Journal of Speech-Language Pathology, 12, 320-332.

Lara N Ledvina, B.M. (2007). The effect of music instruction on reading and literacy scores: Master thesis Graduate school of the Ohio State University.

Mitra, A.(2007). India Non-formal Education: Country Profile Prepared for the Education For All , Global Monitoring Report 2008, Education For All by $\quad$ 2010: we will make it ?

Pakistan One UN Programme Report 2011

Qureshi, S. (2002). Decentralization to district level. (pp. 31-40). Islamabad: Ministry of Education, Pakistan.

Rasheed, M. (2004). Educational administration and supervision. (pp. 145-166). Islamabad: AllamaIqbal Open University.

Rashid, M. (2009). Adult education/literacy. AllamaIqbal Open University Islamabad.

Saleem, M. (2002). Facts and figures. (pp. 07-10). Islamabad: Agha Khan Gee Printers.

Shakir, M., Adeeb, M.A., Lone, A. H \& Jam Muhammad Zafar, J. M. (2011). Unveiling the Veiled Facts: A Survey on Literacy Situation in Pakistan. International Journal of Business and Social Science, 2(12); 265-272

Strassman, P. (1983). Information systems and literacy. In Bailey, R.W. \& Fosheim, R.M. (Eds.), Literacy for life (pp. 115- 121). New York: The Modern Language Association of America.

Wallace, T., Stariha, W. E., \& Walberg, H. J. (2004). Teaching speaking, listening and writing (No. 14). Belgium: International Academy of Education. 